\title{
НОВЫЕ СВЕДЕНИЯ О РЕДКИХ И МАЛОИЗУЧЕННЫХ СКРЕБНЯХ (ACANTHOCEPHALA) ПТИЦ РОССИИ
}

\author{
Г. И. Атрашкевич \\ ФГБУН Институт биологических проблем Севера ДВО РАН, г. Магадан \\ E-mail: gatr@ibpn.ru
}

\begin{abstract}
По материалам с Северо-Запада Чукотки приведены иллюстрированные морфологические описания пяти видов акантоцефалов, являющихся редкими и малоизученными как для фауны акантоцефалов птиц Арктики и Субарктики, так и фауны России в целом: Polymorphus gavii Hohlova, 1965; P. kostylewi Petrotschenko, 1949; Andracantha mergi (Lundström, 1941); Arhythmorhynchus sp. Atrashkevich, 1981 и Bolbosoma sp. Atrashkevich, 1981.
\end{abstract}

Ключевые слова: акантоцефалы, птицы, Чукотка, Арктика, Россия.

DOI: 10.34078/1814-0998-2019-4-73-82

\section{ВВЕДЕНИЕ}

Скребни (колючеголовые черви, акантоцефалы) представляют собой крайне своеобразную, но относительно малочисленную группу паразитических червей, мировая фауна которых по разным оценкам насчитывает всего 13001500 видов (Хохлова, 1986; Amin, 2013). Эти паразиты являют собой отдельный тип животного царства - Acanthocephales (Rudolphi, 1808) Skrjabin et Schulz, 1931 и во взрослом состоянии обитают в пищеварительном тракте позвоночных всех классов, за исключением круглоротых. При этом наибольшим таксономическим разнообразием, как правило, выделяются скребни морских и пресноводных рыб, за которыми следуют скребни птиц. Однако в ряде природных зон и территорий наблюдается обратная картина - скребни птиц наиболее разнообразны и многочисленны в экосистемах, ландшафтах и биоценозах (Петроченко, 1958; Атрашкевич, 2010, 2018; Лисицына, 2019).

В настоящее время можно уверенно констатировать высокое таксономическое и экологическое разнообразие скребней позвоночных животных России: не менее 188 видов 50 родов, 18 семейств, 8 отрядов, 3 классов. И это без учета 30 личиночных и взрослых форм, не идентифицированных до вида и обозначенных в литературе как «species» (Атрашкевич, 2010, 2018).

По нашей оценке, в фауне скребней птиц России к настоящему времени известно не менее 110 видов 21 рода, 10 семейств, 6 отрядов, 3 классов, менее $1 / 3$ из которых можно по праву отнести к широко распространенным и относительно хоро-

(С Атрашкевич Г. И., 2019 шо изученным, а остальных - к малоизученным и редким видам (Атрашкевич, 2013а, б, 2018).

Особое значение в рассматриваемом аспекте имеет изучение биоты Арктики и Субарктики как особого типа физико-географической среды, издавна привлекающего внимание биологов различных специальностей, в том числе паразитологов. Тундровые экосистемы - пресноводные, эстуарные, наземные - характеризуются наличием целого ряда природных очагов инвазий, где скребни в числе других гельминтов реально участвуют в регуляции численности популяций водных и наземных промысловых, редких и охраняемых животных, а также в эпизоотологических и эпидемиологических процессах. При достаточно широком распространении по планете скребни, как правило, имеют низкую частоту встречае мости и лишь в отдельных регионах и экосистемах демонстрируют высокую численность своих паразитических популяций. Именно этим характеризуется группа из 10-15 фоновых видов гидротопических скребней птиц в Арктике, которые здесь в полной мере могут быть причислены к категории доминирующих видов среди других крупных таксонов гельминтов - цестод, трематод и нематод (Атрашкевич, 2010, 2013а, в). Проведенная инвентаризация скребней птиц Субарктики показывает их высокое таксономическое и экологическое разнообразие, отражающее общую характерную черту типа - относительно большое число таксонов высокого ранга. Учтено 79 видов и форм 18 родов, 8 семейств, 5 отрядов, 3 классов. При этом один класс - Palaeacanthocephala (1 отряд, 4 семейства, 14 родов) резко выделяется среди других наибольшим количеством видов (69), включая 3 наиболее представи- 
тельных по количеству видов рода: Polymorphus Lühe, 1911 (17), Corynosoma Lühe, 1904 (11) и Arhythmorhynchus Lühe, 1911 (9). Примерно равное количество видов скребней приходится на Европейский (32) и Американский (35) секторы и вдвое больше - на Азиатский (57), более половины из которых представлены видами как эндемичными для Северо-Востока Азии, так и фоновыми для всей Азиатской Субарктики (Атрашкевич, 2013а, в, 2017).

Сказанное справедливо и для обширных пространств Российской Арктики - гнездовых и нагульных территорий множества водоплавающих и околоводных птиц, у которых в настоящее время известно 67 видов и форм скребней, относящихся к 17 родам, 7 семействам, 4 отрядам и 3 классам. При этом лишь небольшая группа гидротопических скребней (около 10 видов) принадлежит к числу фоновых, массовых паразитов, образующих в Российской Арктике многолетние природные очаги инвазий, а большинство относится к редким и заносным с мест зимовок птиц видам. По количеству видов (16) абсолютно доминирует один род - Polymorphus, в котором не менее 8 видов вызывают обоснованное сомнение либо в своей валидности, либо в правильной идентификации для Евразии (Атрашкевич, 2014, 2017).

Наше почти 30-летнее изучение скребней птиц в Чаунской низменности Чукотки является пионерным для тундровой зоны Арктики, когда, наряду с фаунистическими и таксономическими исследованиями, проводилось полевое изучение жизненных циклов, популяционной биологии и экологии личиночных форм скребней доминирующих видов.

В начальный период этих исследований (19711982 гг.), среди прочего, были получены новые сведения о редких для России и Субарктики видах скребней птиц, а также обнаружены единичные, уникальные экземпляры скребней, идентифицировать которые до вида не представилось возможным. Эти сведения, имеющиеся в диссертационной работе (Атрашкевич, 1981), своевременно не были опубликованы в открытой печати, однако в качестве зарегистрированных фактов (в том числе Arhythmorhynchus sp. и Bolbosoma sp.) были учтены в обобщающей сводке по акантоцефалам наземных позвоночных фауны СССР (Хохлова, 1986). Руководствуясь настоятельными пожеланиями коллег-акантоцефалологов опубликовать эту, полученную нами ранее информацию в оригинальном виде, мы восполняем этот пробел с учетом современных знаний.

\section{МАТЕРИАЛ И МЕТОДЫ}

В основу работы положены результаты повторного изучения коллекции пяти редких для России скребней птиц, собранной нами в 70-е гг. прошлого столетия на базе Чаунского стационара ИБПС ДВО РАН в Чаунской низменно-

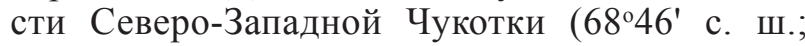
$170^{\circ} 33^{\prime}$ в. д.) и хранящейся в фондах лаборатории экологии гельминтов. Камеральная обработка скребней проведена традиционными в акантоцефалологии методами. Оригинальные рисунки выполнены рисовальным аппаратом РА-6 с небольшой обработкой изображений на современном этапе в программе Adobe Photoshop. Морфология червей изначально изучена с использованием микроскопа Amplival (Carl Zeiss Jena), а в настоящее время Zeiss Axio Imager A1 и Zeiss Axio Imager D1.

Новые сведения получены нами при работе с архивом и коллекционным фондом скребней от птиц Чукотки в Гельминтологическом музее Центра паразитологии Института проблем экологии и эволюции им. А. Н. Северцова РАН, Москва (ГМ ЦП ИПЭЭ РАН). Проанализированы записи в Журналах гельминтологических вскрытий птиц № 1, 2 и 3 («Золотые книги») Чукотской Союзной гельминтологической экспедиции (СГЭ) 1961-1962 гг. № 318 и ревизованы спиртовые фиксации типовых экземпляров скребней Polymorphus gavii Hohlova, 1965 в шести пробирках с инвентарными номерами 130-135.

При указании дефинитивных хозяев скребней в скобках приведено: количество зараженных птиц из числа вскрытых; предельные значения интенсивности инвазии скребнями, экз.; возрастная характеристика обнаруженных скребней - молодые (juv.), половозрелые (subad., для самцов и самок с копуляционными колпачками) и зрелые особи (ad. - самки с яйцами в выводящих путях и самцы размера взрослых особей). Промеры в морфологических описаниях скребней даны, главным образом, в микрометрах, если не указано иное. Научные названия птиц приведены по Е. А. Коблику с соавторами (Коблик и др., 2006), рыб - по В. В. Федорову с соавторами (Федоров и др., 2003) и морских ракообразных по К. В. Регель (2005).

\section{РЕЗУЛЬТАТЫ И ОБСУЖДЕНИЕ}

Все описываемые ниже скребни относятся к одному семейству - Polymorphidae Meyer, 1931 отряда Polymorphida Petrotschenko, 1956 класса Palaeacanthocephala Meyer, 1931.

\section{Polymorphus gavii Hohlova, 1965}

Облигатный паразит гагар. Уникальный, эндемичный вид скребней птиц Чукотки (Хохлова, 1965, 1986; Атрашкевич, 1981, 2014). Публикации других авторов по этом виду скребней в литературе отсутствуют.

Дефинитивные хозяева P. gavii в Чаунской низменности Чукотки: чернозобая гагара Gavia arctica (L., 1758) (у 11 из 58, 2 - более 1000 экз., juv.- 
ad.); морянка Clangula hyemalis (L., 1758) (у 2 из 266, по 1 экз., juv.) - в качестве хозяина зарегистрирована впервые (Атрашкевич, 1981). Сейчас общеизвестно, что в приморских тундрах крайнего Северо-Востока России симпатрично обитают два вида сходных по облику и экологическим особенностям гагар - чернозобая Gavia arctica и белошейная G. pacifica (Lawrence, 1858) (Нечаев, Гамова, 2009; Соловьева и др., 2017). В 1970 -е гг. белошейная гагара в тундрах Чаунской низменности повсеместно уступала в численности чернозобой гагаре с 5-20-кратной разницей (Кречмар и др., 1991), однако, по современным данным, белошейная гагара - самая распространенная и многочисленная из гагар не только в Чаунской низменности, но и на всей Чукотке (Соловьева и др., 2017). В связи с этим особи G. pacifica c большой долей вероятности могли быть в числе 58 вскрытых и 11 зараженных $P$. gavii гагар, считавшихся нами в то время одним видом чернозобой гагарой. Гагары двух других видов 18 экз. краснозобой гагары G. stellata (Pontoppidan, 1763) и 11 экз. белоклювой - G. adamsii (G. R. Gray, 1859), исследованных нами в Чаунских приморских тундрах, в качестве хозяев $P$. gavii не отмечены.

Локализация скребней - тонкий кишечник птиц, значительно реже - прямая кишка, в единичных случаях - слепые отростки.

Располагая массовым материалом по P. gavii (кишечник одной гагары на всем протяжении, начиная от тонкого его отдела, был поражен более 1000 экз. разновозрастных скребней), мы имели возможность детально сопоставить его с первоописанием, добавив новые сведения и исправив две принципиальные ошибки, до сего времени существующие в литературе (Хохлова, 1965, 1986; Каталог..., 2009).

В первоописании $P$. gavii указана яркая отличительная черта вида от всех представителей p. Polymorphus наличие хорошо выраженных корней абсолютно у всех хоботковых крючьев, включая базальные (Хохлова, 1965), чего мы не наблюдали ни у одного экземпляра этого вида в нашей коллекции. Ревизия скребней в коллекции ГМ ЦП ИПЭЭ РАН с использованием светового микроскопа AXIO Imager A1 с контрастом Номарского не подтвердила наличие указанного отличительного признака и у типовых экземпляров $P$. gavii $a$

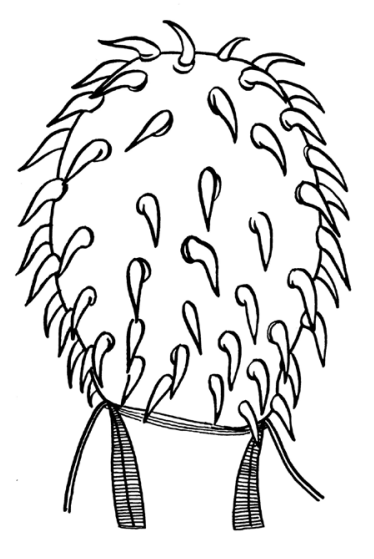

6

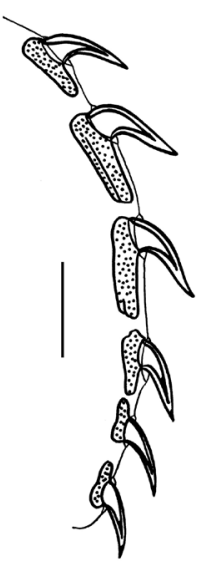

Puc. 1. Polymorphus gavii Hohlova, 1965: $a$ - хоботок самца от чернозобой гагары $G$. arctica, $\sigma$ - крючья продольного ряда. Масштабные линейки: $a-0.2$ мм; б- 0.1 мм. Оригинал

Fig. 1. Polymorphus gavii Hohlova, 1965: $a$ - proboscis of a male from $G$. arctica, $\sigma$ - longitudinal row hooks. Scale bars: $a-0.2 \mathrm{~mm} ; \sigma-0.1 \mathrm{~mm}$. Original

(№ 130-135). Таким образом, морфология хоботковых крючьев этого вида тождественна таковым для всех остальных представителей рода - наличие только рудиментарных корней у одного-двух базальных крючьев в задней части хоботка (рис. 1 , б), что соответствует диагнозу p. Polymorphus в peвизии, предпринятой О. М. Амином (Amin, 1992).

В остальном морфологическая характеристика взрослых скребней $P$. gavii из нашей коллекции с Северо-Запада Чукотки вполне соответствует таковой в первоописании вида от гагар с восточной окраины Чукотского полуострова (Хохлова, 1965), обнаруживая при этом некоторые отличия в величинах по ряду основных признаков (см. таблицу).

Основные морфологические признаки Polymorphus gavii Basic morphological features of Polymorphus gavii

\begin{tabular}{|c|c|c|c|}
\hline \multicolumn{2}{|c|}{ Морфологический признак } & По Хохловой, 1965 & Наши данные \\
\hline \multirow{2}{*}{$\begin{array}{l}\text { Общая длина скреб- } \\
\text { ней, мм }\end{array}$} & Самец & $5.75-6.88$ & $4.45-7.05$ \\
\hline & Самка & $6.13-7.03$ & $4.57-7.50$ \\
\hline \multicolumn{2}{|c|}{$\begin{array}{l}\text { Размер округлого, зачастую } \\
\text { шаровидного хоботка }\end{array}$} & $460-535 \times 351-460$ & $445-541 \times 364-435$ \\
\hline \multicolumn{2}{|c|}{$\begin{array}{l}\text { Формула хоботкового воору- } \\
\text { жения }\end{array}$} & $13-14 \times 5-6$ & $\begin{array}{c}13-16 \times 5-7 \\
\text { (обычно 14-15 × 5-6) }\end{array}$ \\
\hline \multirow{2}{*}{$\begin{array}{l}\text { Размер острия наи- } \\
\text { больших крючьев } \\
\text { (II-III) }\end{array}$} & Длина & $96-110$ & $81-107$ \\
\hline & Толщина & $25-34$ & $22-31$ \\
\hline \multirow{2}{*}{$\begin{array}{l}\text { Размер корней наи- } \\
\text { больших крючьев }\end{array}$} & Длина & $93-114$ & 74-99 \\
\hline & Толщина & $25-28$ & $25-31$ \\
\hline \multicolumn{2}{|l|}{ Размер семенников } & $613-920 \times 535-766$ & $489-825 \times 390-599$ \\
\hline \multicolumn{2}{|l|}{ Размер зрелых яиц } & $120-130 \times 20-25$ & $108-130 \times 19-24$ \\
\hline
\end{tabular}


Таким образом, при малой величине тела (самки до 7.5 мм) скребни P. gavii выделяются среди известных представителей p. Polymorphus наибольшей величиной хоботковых крючьев при относительно малом их количестве (Хохлова, 1971; Amin, 1992). По нашему материалу длина острия даже самых мелких, базальных хоботковых крючьев $P$. gavii, имеющих рудиментарные корни, составляет 68-91 при толщине острия 21-24.

В первоописании $P$. gavii (Хохлова, 1965) имеется следующая запись о дефинитивных хозяевах скребня: «чернозобая гагара Gavia arctica (у 4 из $14,1-15$ экз.); полярная гагара Gavia immer (у 1 одной вскрытой, 47 экз.)». Здесь закралась вторая ошибка в отношении $P$. gavii, повторяющаяся во всех дальнейших публикациях по виду (Ryzhikov et al., 1985; Хохлова, 1986; Каталог..., 2009; и др.) и касающаяся хозяина скребня, указанного в качестве типового, а именно черноклювой («полярной») гагары - G. immer (Brünnich, 1764), что, как выяснилось, не является достоверным фактом. На самом деле это белоклювая гагара G. adamsii, о чем свидетельствуют архивные записи и коллекция ГМ ЦП ИПЭЭ РАН. В журнале № 2 вскрытий птиц Чукотской СГЭ № 318 за 1961 г. имеется запись об интересующем нас единственном вскрытом и зараженном $P$. gavii экземпляре «полярной» гагары под номером вскрытия 219: «Gavia adamsii; взрослая самка, добыта 27 июня 1961 г. в р-не пос. Уэлькаль. Чукотка». Там же, в ГМ ЦП ИПЭЭ РАН в коллекции скребней птиц Чукотки в пробирке с инвентарным № 130, содержащей голотип (самец) и аллотип (самка) P. gavii, находится этикетка с надписью: «Gavia immer adamsii № 219, тонкий к-к. Чукотка, Уэлькаль. 27.06.1961 г.». Во второй пробирке (№ 131), содержащей паратипы $P$. gavii от этого же хозяина, на этикетке обозначено только одно латинское название гагары - Gavia adamsii.

Таким образом, типовым дефинитивным хозяином P. gavii является белоклювая гагара $G$. adamsii, а типовой территорией вида - окрестности пос. Уэлькаль Чукотского полуострова (653' с. ш.; $179^{\circ} 17^{\prime}$ з. д.). Заметим, что белоклювая гагара - гнездящийся перелетный, мигрирующий и зимующий вид на Северо-Востоке России, в то время как северо-американская черноклювая («полярная») гагара встречается у берегов Дальнего Востока России (до акватории Японского моря) только в период сезонных миграций и летних кочевок (Нечаев, Гамова, 2009; Соловьева и др., 2017). Судя по имеющимся показателям зараженности, основным облигатным дефинитивным хозяином скребня P. gavii вдоль морских побережий Чукотки от Чаунской низменности до Анадыря является чернозобая гагара G. arctica, a с учетом современных данных о гагарах Чукотки (Соловьева и др., 2017) это может быть и другой близкий вид - белошейная гагара G. pacifica.
Статус морянки как дефинитивного хозяина по степени естественной восприимчивости к скребню остается неопределенным.

Биология скребня P. gavii до сего времени не изучена. Однако можно утверждать, что этот паразит относится к морской экологической группе и его жизненный цикл связан с какими-то прибрежными морскими бокоплавами в качестве промежуточных хозяев, что предполагала и И. Г. Хохлова (1965), сравнивая экологию двух исследованных ею гагар - чернозобой $G$. arcti$c a$ и краснозобой G. stellata. В морском образе жизни личиночных форм $P$. gavii нас убеждают факты обнаружения молодых скребней, в том числе особей чуть старше цистаканта (с инвагинированным задним отделом метасомы) у гагар и морянок в период их гнездования на морских побережьях Чаунской низменности, а также в коллекционном материале ГМ ЦП ИПЭЭ РАН от гагар Восточной Чукотки. Кроме того, $P$. gavii встречается у гагар совместно с другим видом скребней - P. phippsi Kostylew, 1922, широко распространенным паразитом морских птиц в высоких широтах, промежуточным хозяином которого на Чукотке, по нашим данным, является морской прибрежный бокоплав сем. Gammaridae - Gammarus (Lagunogammarus) setosus (Dementieva, 1931). Промежуточными хозяевами еще одного широко распространенного скребня рыбоядных птиц - Corynosoma strumosum (Rudolphi, 1802), встречающегося у гагар совместно с P. gavii, являются также прибрежные морские бокоплавы сем. Anisogammaridae, установленные в Северном Охотоморье, -Eogammarus schmidti (Derzhavin, 1927), Locustogammarus locustoides (Brandt, 1851) и Spinulogammarus ochotensis (Brandt, 1851) (Атрашкевич, 2009).

\section{Polymorphus kostylewi Petrotschenko, 1949}

Редкий и малоизученный вид акантоцефалов птиц, описанный от обыкновенного турпана Melanitta fusca (L., 1758) с нижней Сыр-Дарьи в Казахстане (Петроченко, 1958). Был обнаружен также у домашних уток в Азербайджане и у диких уток в двух регионах России - у морской чернети Aythya marila (L., 1761) в Якутии и у чиркасвистунка Anas crecca L., 1758 на Сахалине (Xoxлова, 1986).

Дефинитивные хозяева P. kostylewi в Чаунской низменности Чукотки: сибирская гага Polysticta stelleri (Pallas, 1769) (у 1 из 10, 1 экз., subad., 12 июня 1971 г.), очковая гага Somateria fischeri (J. F. Brandt, 1847) (у 1 из 56, 1 экз., subad., 10 июня 1971 г.). Гаги - новые хозяева $P$. kostylewi, и это первая регистрация паразита у птиц в Субарктике (Атрашкевич, 1981).

Локализация скребней - тонкий кишечник.

Самка P. kostylewi (незрелая) от сибирской гаги P. stelleri (рис. 2, a). Общая длина скреб- 
ня 3.70 мм. Метасома грушевидная, длиной 2.76 мм при максимальной ширине 1.69 мм. Хоботок удлиненно-овальный $-610 \times 235$. Формула хоботкового вооружения $-17 \times 9-10$. Длина острия наиболее мощных крючьев (V-VII) - 67-72 при толщине 21-22. Длина корней этих крючьев достигает 67-74, толщина - 22-24. Длина шейки 387 при ширине в основании 562 и у хоботка 226. Длина хоботкового влагалища 1125 , максимальная ширина - 402. Лемниски широкие, уплощенные, листовидные. Вентральное протяжение зоны метасомных шипиков до 1131, а дорсальное - лишь до 505. Яйца отсутствуют. В полости метасомы скребня имеется небольшое количество яйцевых шаров, диаметр наибольших 109-146.

Половозрелый самец $\boldsymbol{P}$. kostylewi от очковой гаги $S$. fischeri (рис. 2, б). Общая длина скребня 5.38 мм, длина грушевидной метасомы 4.35 мм при ширине в области семенников 1.86 мм. Хоботок овально-цилиндрический $599 \times 234$. Формула хоботкового вооружения $16 \times 10-11$. Длина острия наиболее мощных крючьев (V-VII) достигает 65-68 при толщине 1922. Шейка относительно короткая, ее длина (438) меньше ширины в основании (528). Ширина шейки у хоботка - 183. Длина хоботкового влагалища 1044, максимальная ширина - 394. Лемниски широкие, уплощенные, листовидные (как у самки), длиной до 729 при ширине до 470. Вентральное протяжение зоны метасомных шипиков - до 1.79 мм, а дорсальное - до 1.39 мм. Общая длина шипиков 26-31. Семенники ориентированы по линии, перпендикулярной продольной оси метасомы; их размер $825-831 \times 581-592$, что в 2 раза превышает размеры семенников $P$. kostylewi, отмеченные В. И. Петроченко (1958). Цементные железы трубчатые, в количестве четыpex, длиной 1044-1166. Протяженность протоков цементных желез 818 .

Биология P. kostylewi не изучена.

\section{Andracantha mergi \\ (Lundström, 1941) Schmidt, 1975}

Относительно редкий и малоизученный вид акантоцефалов Евразии и Северной Америки, описанный как Corynosoma mergi от длинноносого крохаля Mergus serrator (L., 1758) в Швеции. На территории бывшего CCCP A. mergi известен только у различных рыбоядных птиц Дальнего Востока России (Хохлова, 1986).

Дефинитивный хозяин $A$. mergi в Чаунской низменности Чукотки - чернозобая гагара (у 1 из 58, 1 экз., subad., 15 июля 1974 г.). Это первая находка скребня у этого хозяина и его первая регистрация в Субарктике (Атрашкевич, 1981).

Локализация скребня - тонкий кишечник.

Приводим краткое описание обнаруженной половозрелой (судя по величине) самки A. mergi (рис. 3).

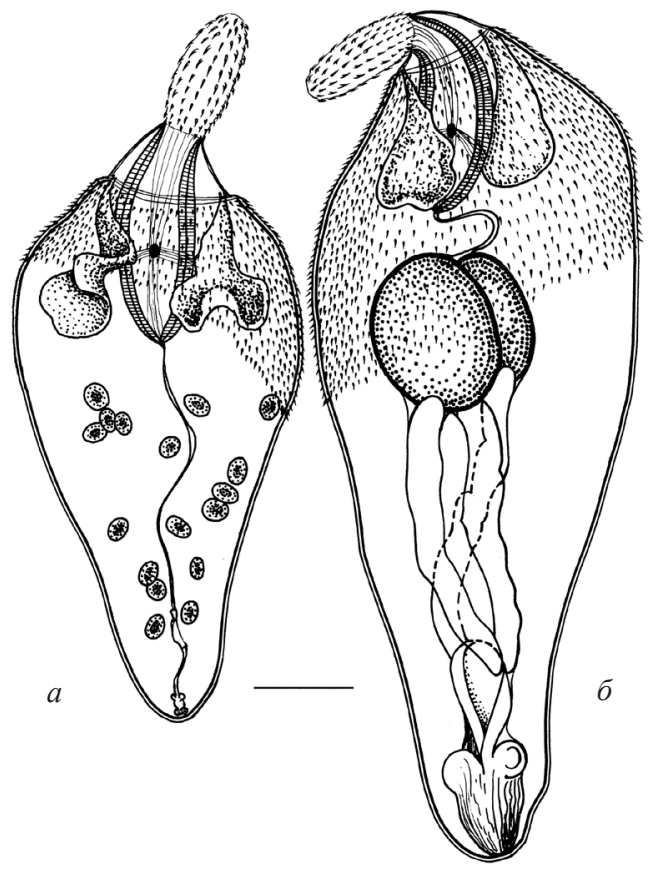

Puc. 2. P. kostylewi Petrotschenko, 1949: $a$ - самка от сибирской гаги P. stelleri; $\sigma$ - самец от очковой гаги S. fischeri. Масштабная линейка 0.5 мм. Оригинал

Fig. 2. P. kostylewi Petrotschenko, 1949: $a-$ female from P. stelleri; $\sigma$ - male from S. fischeri. Scale bar $0.5 \mathrm{~mm}$. Original

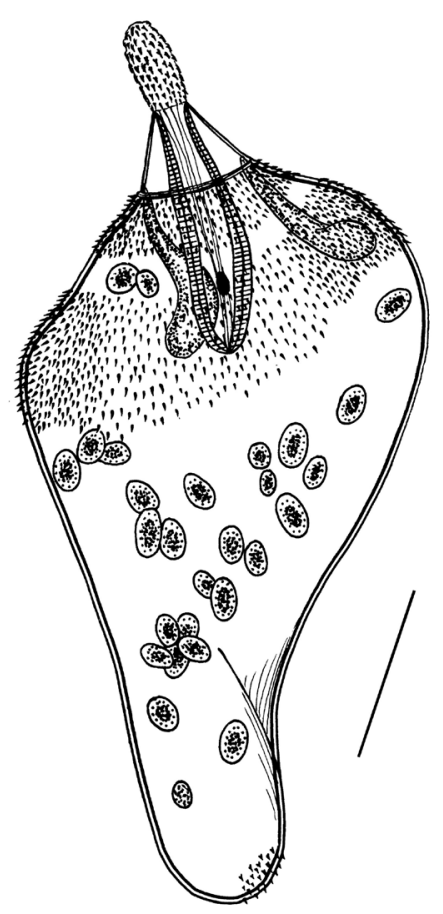

Puc. 3. Andracantha mergi (Lundström, 1941) Schmidt, 1975: самка с яйцевыми шарами в полости тела. Масштабная линейка 1.0 мм. Оригинал

Fig. 3. Andracantha mergi (Lundström, 1941) Schmidt, 1975: female with ovarian balls in the body cavity. Scale bar $1.0 \mathrm{~mm}$. Original 
Общая длина скребня 5.26 мм при максимальной ширине грушевидной метасомы 2.44 мм. Хоботок $568 \times 248$. Формула хоботкового вооружения $-16 \times 9-10$. Максимальная длина острия хоботковых крючьев (медианных) 62-70 при толщине до 24 и при длине корней 68-72. Длина хоботкового влагалища 1485 , ширина - 385. Шейка коническая, ее длина 508 при ширине в основании 665 и у хоботка -205 . Передний отдел метасомы скребня покрыт двумя «поясами» шипиков длиной 24-26. Ширина переднего «пояса» шипиков 258-398, второго - 648-818. Участок метасомы, разделяющий зоны шипиков, достигает ширины 161-357. Узкий участок метасомы вокруг полового отверстия самки покрыт мелкими шипиками. Яиц нет. В полости метасомы имеется небольшое количество яйцевых шаров диаметром 283-318.

Сведения о реализации жизненного цикла $A$. mergi в Субарктике отсутствуют, однако известный состав дефинитивных хозяев скребня однозначно свидетельствует о принадлежности вида к морской экологической группе паразитов. Южнее, в Северном Охотоморье $A$. mergi является фоновым облигатным паразитом очкового чистика Cepphus carbo Pallas, 1811, встречаясь также у длинноносого M. serrator и большого M. merganser Linnaeus, 1758 крохалей, чернозобой гагары G. arctica и тихоокеанской чайки Larus schistisagus Stejneger, 1884 (Атрашкевич, 2009). В Ceверном Охотоморье впервые были установлены естественные хозяева скребней рода Andracantha Schmidt, 1975: промежуточный - прибрежный бокоплав Orchomenella minutus (Kroyer, 1846) сем. Lysianassidae и паратенический - тихоокеанская треска Gadus macrocephalus Tilesius, 1810 (Атрашкевич, 2009). Дополнительное морфологическое и экологическое изучение обнаруженных при этом цистакантов позволило нам идентифицировать их как $A$. mergi и установить в Северном Охотоморье нового паратенического хозяина скребня - желтоперую камбалу Limanda aspera (Pallas, [1814]).

\section{Arhythmorhynchus sp. Atrashkevich, 1981}

Дефинитивный хозяин паразита в Чаунской низменности Чукотки - камнешарка Arenaria interpres (L., 1758) (у 1 из 44, 1 экз.). К сожалению, мы располагаем лишь хоботком с шейкой этого скребня, извлеченного из тонкого кишечника птицы 30 мая 1971 г. Признаки хоботкового вооружения и систематический статус хозяина позволяют отнести обнаруженного скребня к роду Arhythmorhynchus, однако не соответствуют диагнозу ни одного из известных ныне представителей этого рода (Хохлова, 1975).

Хоботок Arhythmorhynchus sp. овальновытянутый, длиной 1.250 мм с расширением в средней части до 0.405 мм (рис. 4, $a$ ). Длина шей- ки 416 при ширине в основании около 297 и у хоботка 142. Для точного подсчета крючьев инвагинированного на $1 / 3$ хоботка нам пришлось его препарировать до полной разверстки. Хоботок вооружен неравнозначными по величине и форме крючьями, расположенными в 18 продольных рядов по 15-16 крючьев в ряду. Первые пять крючьев каждого продольного ряда (рис. 4, в) - крупные (длина острия 77-84, толщина 22-26), с хорошо развитыми корнями (длина корня 51-86, ширина до 22-36). В месте максимального расширения хоботка в каждом продольном ряду имеются 1-2 (чередуются в рядах) наиболее мощных крючка, выделяющихся среди других своей величиной и формой (рис. 4,6$)$. Длина острия этих крючьев (VI-VII от вершины хоботка) 86-103, толщина 36-38. Длина их корней 103-118 при максимальной ширине 31-41. За одним-двумя мощными крючьями каждого ряда имеется по одному относительно маленькому крючку (VII-VIII), длина острия которого лишь 38-48 при толщине 12-14 (рис. 4, г).
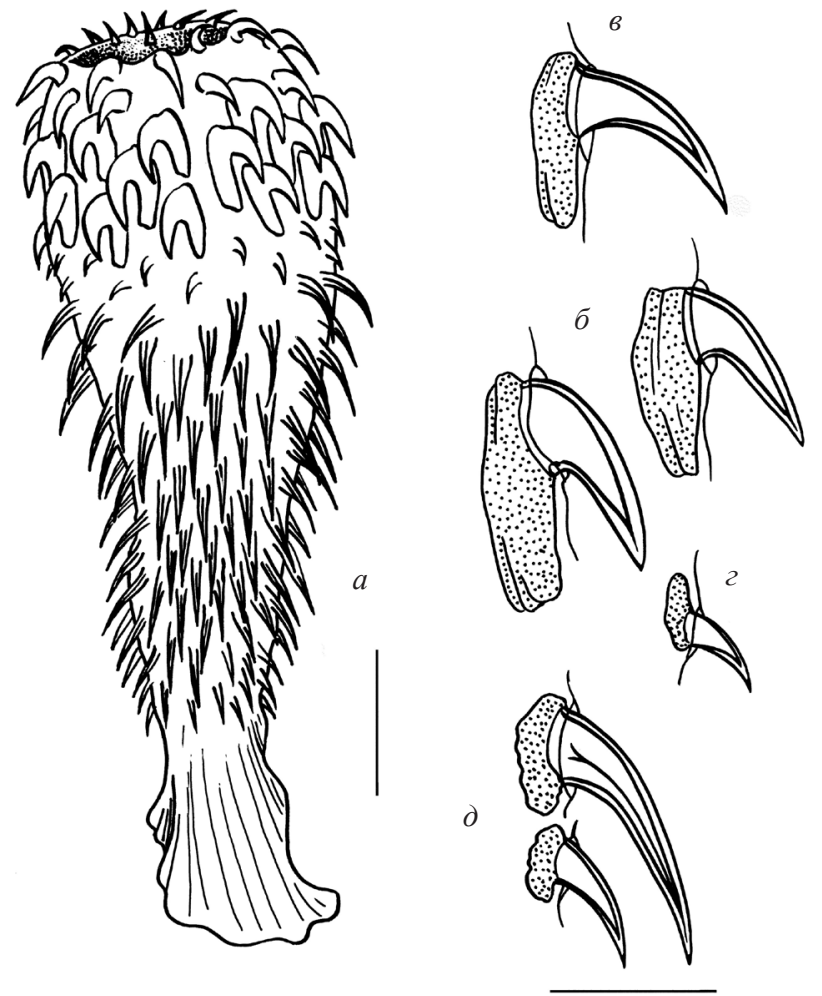

Puc. 4. Arhythmorhynchus sp. Atrashkevich, 1981: $a$ - хоботок (общий вид); $\sigma$ - наиболее мощные крючья (VI-VII); в - крючья I-V; 2 - наиболее мелкие крючья (VII-VIII); $\partial$ - крючья-иглы. Масштабные линейки: $a-0.2$ мм; $\sigma, 6,2, \partial-0.1$ мм. Оригинал

Fig. 4. Arhythmorhynchus sp. Atrashkevich, 1981: $a$ - proboscis (total view); $\sigma$ - most massive hooklets (VI-VII); 6 - hooklets I-V; 2 - smallest hooklets (VIIVIII); $\partial$ - hooklets-spines. Scale bars: $a-0.2 \mathrm{~mm} ; \sigma, \beta$, г, $\partial-0.1 \mathrm{~mm}$. Original 
Далее к основанию хоботка располагаются самые длинные крючья-иглы, имеющие рудиментарные корни (рис. 4,d). Длина их острия достигает 98-120 при толщине до 24-29. Длина острия базальных крючьев в основании хоботка - до 55.

По характеру вооружения хоботка к описываемому скребню близок лишь один вид рода Arhythmorhynchus - типовой A. frassoni (Molin, 1858) (Хохлова, 1975). Однако на хоботке $A$. frassoni в каждом продольном ряду по 20 крючьев (у Arhythmorhynchus sp., соответственно - 15-16), и 2 наиболее мощных, выделяющихся из всех крючка имеются лишь в трех продольных рядах на вентральной стороне хоботка, в то время как у Arhythmorhynchus sp. такие крючья характерны для каждого продольного ряда по всему периметру хоботка. К сожалению, отсутствие метасомы не позволяет описать обнаруженного скребня в качестве нового вида, определенно занесенного камнешаркой $A$. interpres с мест ее зимовки в Юго-Восточной Азии или Австралии (Нечаев, Гамова, 2009).

\section{Bolbosoma sp. Atrashkevich, 1981}

Дефинитивный хозяин скребня в Чаунской низменности Чукотки - серощекая поганка Podiceps grisegena (Boddaert, 1783) (у 1 из 2, 1 экз., ad., 6 июля 1975 г.).

Локализация скребня - прямая кишка.

К сожалению, обнаруженный зрелый экземпляр самки не имеет хоботка и шейки (оборваны при вскрытии кишечника птицы), однако строение его метасомы и другие сопутствующие морфологические признаки, имеющие таксономическое значение, в целом соответствуют диагнозу p. Bolbosoma Porta, 1908 и выделяют этого скребня из всех известных в составе рода представителей (Yamaguti, 1963).

Общая длина скребня 5.85 мм. Оранжевого цвета метасома четко подразделяется на три отдела. Передний, длиной 0.964 мм, бульбусообразно расширяющийся до 1.786 мм, густо усеян шипиками, расположенными в тегументных бугорках (рис. 5, a). Общая длина этих шипиков 27-34 при длине острия 23-29 и толщине 3-5. Средний, зауженный отдел метасомы испещренпродольными бороздками и имеет плотные покровы. Его длина 1.906 мм, ширина у бульбуса 1.175 мм и минимальная ширина 0.494 мм. Задний отдел метасомы - овально-цилиндрическкй, длиной 2.585 мм при максимальной ширине 1.034 мм, в котором располагаются выводящие пути половой системы самки общей протяженностью 629. Задний отдел оканчивается коротким, сосцевидным выступом $-259 \times 306$. По всей вентральной поверхности среднего и заднего отделов метасомы наблюдаются редко расположенные, относительно мелкие шипики длиной 24-27 (рис. 5, б), что не отмечено ни для одного из известных видов больбосом. Полость метасомы самки, особенно передний, бульбусовидный ее отдел, заполнена развивающимися и зрелыми яйцами, среди которых наблюдаются отдельные яйцевые шары диаметром 165-177. Размер яиц, содержащихся в матке и маточном колоколе скребня, 89-106 × 50-55. Размер акантора - 70-84 × 24-31. Яйца овальные, с плотной средней оболочкой, не имеющей полярных пролонгаций (рис. 5, в), что является еще одной отличительной чертой описываемого скребня. Половое отверстие самки - терминальное.

В заключение следует отметить, что в целом восточные окраины России и Северной Азии, включенные в глобальный восточноазиатскоавстралийский миграционный путь разнообразных водоплавающих и околоводных птиц, не-

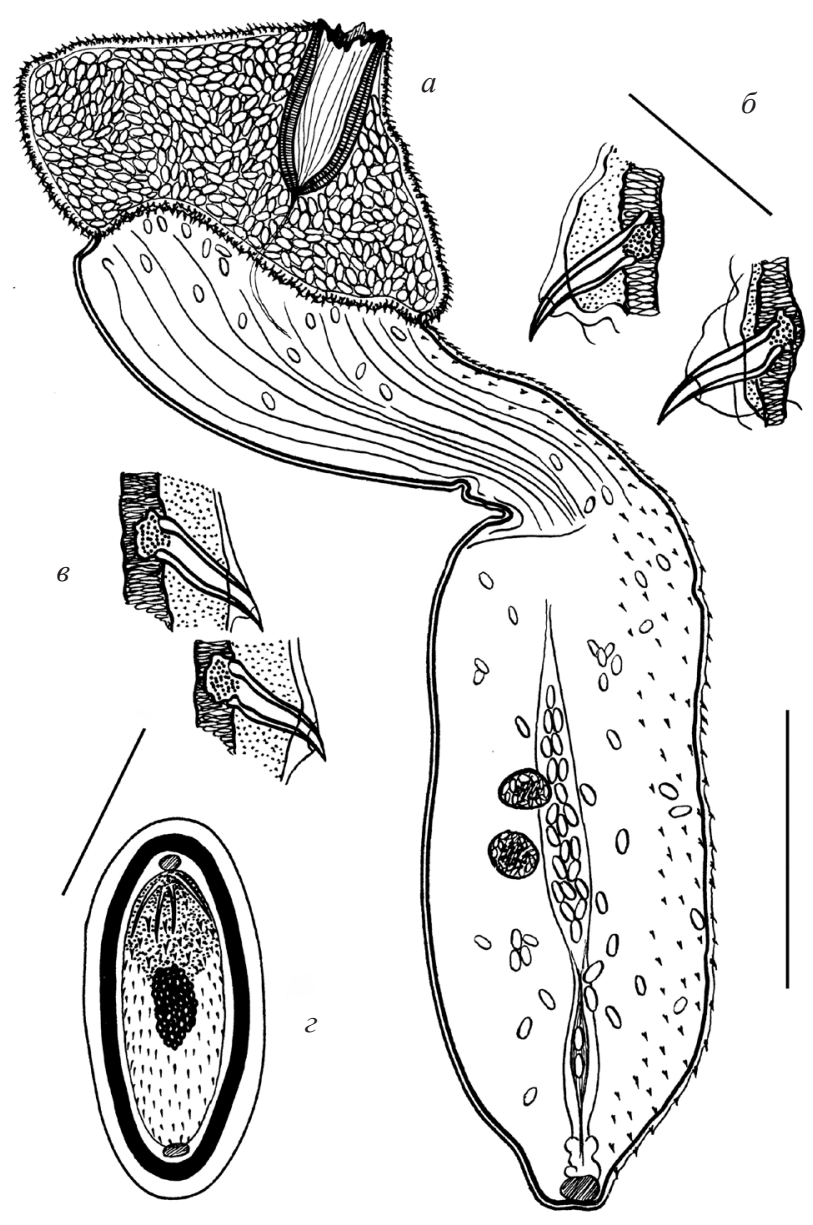

Puc. 5. Bolbosoma sp. Atrashkevich, 1981: $a$ - самка (общий вид); $\sigma$ - метасомные шипики бульбуса; в - вентральные метасомные шипики; г-яйцо. Масштабные линейки: $a-1.0$ мм; 6, в, г- 0.05 мм. Оригинал

Fig. 5. Bolbosoma sp. Atrashkevich, 1981: $a-\mathrm{fe}-$ male (total view); $\sigma-$ metasomal spines of bulbus; $8-$ ventral metasomal spines; 2 - egg. Scale bars: $a-1.0 \mathrm{~mm}$; $\sigma, 6,2-0.05 \mathrm{~mm}$. Original 
обычайно перспективны в плане изучения их разнообразных групп гельминтов, что, несомненно, приведет к обнаружению новых видов и регистраций скребней для фауны России.

Автор искренне признателен сотрудникам ЦП ИПЭЭ РАН - заведующей Гельминтологическим музеем, к. б. н. Л. В. Филимоновой и с. н. с., к. б. н. С. Г. Соколову за содействие и помощь в работе с архивными и коллекционными материалами.

Работа выполнена в рамках научного проекта по госзаданию АААА-А17-117012710031-6 (ИБПС ДВО PAH).

\section{ЛИТЕРАТУРА}

Атрашкевич Г. И. Акантоцефалы птиц СевероЗападной Чукотки (фауна, жизненные циклы, экология) : автореф. дис. ... канд. биол. наук. М., 1981. 24 с.

Атрашкевич Г. И. Биоразнообразие скребней (Acanthocephala) Азиатской Субарктики // Паразиты Голарктики : сб. науч. статей Междунар. симп. (4-8 окт. 2010 г., г. Петрозаводск, Карелия, Россия). Петрозаводск, 2010. С. 23-26.

Атрашкевич Г. И. Биоразнообразие скребней (Acanthocephala) птиц Азиатской Субарктики // Чтения памяти акад. К. В. Симакова : Материалы докл. Всерос. науч. конф. (Магадан, 26-28 нояб. 2013 г.); [отв. ред. И. А. Черешнев]; редкол. Н. А. Горячев и др. Магадан : СВНЦ ДВО РАН, 2013в. С. 118-120.

Атрашкевич Г. И. Новые данные по фауне, систематике и биологии скребней птиц Российской Арктики // Систематика и экология паразитов. М. : Тов-во науч. изданий КМК, 2014. С. 19-21. (Тр. Центра паразитологии. Центр паразитологии Института проблем экологии и эволюции им. А. Н. Северцова РAH ; т. 48).

Атрашкевич Г. И. О жизни гельминтов птиц в Арктике (биоразнообразие и жизненные стратегии на примере скребней) // Чтения памяти акад. К. В. Симакова : Материалы докл. Всерос. науч. конф. (Магадан, 22-24 нояб. 2017 г.). Магадан : ИП Жарикова T. B., 2017. C. 118-120.

Атрашкевич Г. И. Скребни (Acanthocephala) в бассейне Охотского моря: таксономическое и экологическое разнообразие // Тр. ЗИН РАН. 2009. Т. 313, № 3. C. 350-358.

Атрашкевич Г. И. Скребни (Acanthocephala) птиц России: история изучения, итоги, перспективы // Паразитология в изменяющемся мире : Материалы V Съезда Паразитолог. о-ва при РАН / ред. К. В. Галактионов / Всерос. конф. с междунар. участием (2326 сент. 2013 г., ИСиЭЖ СО РАН, Новосибирск). Новосибирск : Гарамонд, 2013б. С. 16.

Атрашкевич Г. И. Скребни (Acanthocephala) птиц Субарктики // Проблемы изучения и охраны животного мира на Севере : Материалы докл. II Всерос. конф. с междунар. участием (Сыктывкар, Республика Коми, Россия, 8-12 апр. 2013 г.). Сыктывкар : Коми НЦ УрО, 2013a. C. 8-10.

Атрашкевич Г. И. Скребни (Acanthocephala) фауны России: состояние изученности, проблемы и пер- спективы : Материалы VI съезда Паразитолог. о-ва / ред. К. В. Галактионов, С. Г. Медведев, А. Ю. Рысс, А. О. Фролов / Междунар. конф. «Современная паразитология - основные тренды и вызовы» (1519 окт. 2018 г., Зоол. ин-т РАН, Санкт-Петербург). СПб. : Лема, 2018. С. 22.

Каталог типовых экземпляров нематод и акантоцефал Гельминтологического музея РАН / отв. ред. С. В. Зиновьева. М. : Тов-во науч. изданий КМК, 2009. 457 с.

Коблик Е. А., Редькин Я. А., Архипов В. Ю. Список птиц Российской Федерации. М. : Тов-во науч. изданий КМК, 2006. 256 с.

Кречмар А. В., Андреев А. В., Кондратьев А. Я. Птицы северных равнин. Л. : Наука, 1991. 288 с.

Лисииьна О. И. Фауна Украины. Т. 31. Акантоцефалы. Киев : Наук. думка, 2019. 223 с.

Нечаев В. А., Гамова Т. В. Птицы Дальнего Востока России (аннотированный каталог). Владивосток : Дальнаука, 2009. 564 с.

Петроченко В. И. Акантоцефалы (скребни) домашних и диких животных. М. : Изд-во АН СССР, 1958. T. 2. 458 c.

Регель $K$. В. Морские и солоноватоводные беспозвоночные Тауйской губы // Биологическое разнообразие Тауйской губы Охотского моря. Владивосток : Дальнаука, 2005. С. 479-544.

Соловьева Д. В., Парук Дж. Д., Тэш Дж. и др. Численность, послегнездовая плотность и особенности использования озер гагарами на Западной Чукотке // Сибир. эколог. журн. 2017. 6. С. 798 811.

Федоров В. В., Черешнев И. А., Назаркин М. В. $u$ др. Каталог морских и пресноводных рыб северной части Охотского моря. Владивосток : Дальнаука, 2003. 204 c.

Хохлова И. Г. Акантоцефалы наземных позвоночных фауны СССР. М. : Наука, 1986. 278 с.

Хохлова И. Г. К ревизии рода Polymorphus Lühe, 1911 (Acanthocephala: Polymorphidae) // Тр. ГЕЛАН CCCP. 1971. T. 21. C. 120-126.

Хохлова И. Г. Ревизия рода Arhythmorhynchus Lühe, 1911 (Acanthocephala: Polymorphidae) // Там же. 1975. T. 25. C. 195-203.

Хохлова И. Г. Polymorphus gavii sp. nov. - новый вид акантоцефал от гагар Чукотки // Тр. ГЕЛАН СССР. М. : Наука, 1965. Т. 15. С. 196-199.

Amin O. M. Classification of the Acanthocephala // Folia Parasitologica. 2013. Vol. 60, No. 4. P. 273-305.

Amin O. M. Review of the genus Polymorphus Lühe, 1911 (Acanhocephala: Polymorphidae), with the synonymization of Hexaglandula Petrochenko, 1950, and Subcorynosoma Hoklova, 1967, and a key to the species // Qatar University Science Journal. 1992. 12. P. 115-123.

Ryzhikov K. M., Rysavy B., Khokhlova I. G., et al. Helminths of Fish-Eating Birds of the Palaearctic Region II. Cestoda and Acanthocephales / eds. K. M. Ryzhikov, B. Rysavy. Moscow - Prague, 1985. 412 p.

Yamaguti S. Acanthocephala. Systema Helminthum. Wiley InterScience, New York, London, 1963. 5. $423 \mathrm{p}$. 


\title{
NEW DATA ON RARE AND POORLY STUDIED SPINY-HEADED WORMS (ACANTHOCEPHALA) FROM BIRDS OF RUSSIA
}

\author{
G. I. Atrashkevich \\ Institute of Biological Problems of the North, FEB RAS, Magadan
}

\begin{abstract}
Based on materials from the north-west of Chukotka, the paper presents illustrated morphological descriptions of five species of birds' acanthocephalans, rare and insufficiently studied both for the Arctic and Subarctic acanthocephalan fauna and for the fauna of Russia, in general: Polymorphus gavii Hohlova, 1965; P. kostylewi Petrotschenko, 1949; Andracantha mergi (Lundström, 1941); Arhythmorhynchus sp. Atrashkevich, 1981 and Bolbosoma sp. Atrashkevich, 1981.
\end{abstract}

Keywords: spiny-headed worms, birds, Chukotka, the Arctic, Russia.

\section{REFERENCES}

Amin O. M., 1992, Review of the Genus Polymorphus Lühe, 1911 (Acanhocephala: Polymorphidae), with the Synonymization of Hexaglandula Petrochenko, 1950, and Subcorynosoma Hoklova, 1967, and a Key to the Species, Qatar University Science Journal, 12, 115-123.

Amin, O. M., 2013, Classification of the Acanthocephala, Folia Parasitologica, 60, 4, 273-305.

Atrashkevich, G. I., 1981, Acanthocephalans of Birds of the Northwest Chukotka, Diss. ... Cand. Sci. (Biology), Moscow [In Russian].

Atrashkevich, G. I., 2009, Spiny-Headed Worms (Acanthocephala) in the Basin of the Sea of Okhotsk; Taxonomic and Ecological Diversity, Proceedings of the Zoological Institute of the RAS, St. Petersburg, 313, 3, 350-358 [In Russian].

Atrashkevich, G. I., 2010, Biodiversity of the SpinyHeaded Worms (Acanthocephala) of the Asian Subarctic, Parasites of the Holarctic: Proceedings of the International Symposium (October 4-8, 2010, Petrozavodsk, Karelia, Russia), Petrozavodsk, 23-26 [In Russian].

Atrashkevich, G. I., 2013a, Spiny-Headed Worms (Acanthocephala) from the Birds of the Subarctic Region, Problems of Animals Study and Protection in the North : Proceedings of II Russian Scientific Conference (Syktyvkar, Komi Republic, Russia, April 8-12, 2013), Syktyvkar, Komi Scientific Centre, Ural Branch, RAS, 8-10 [In Russian].

Atrashkevich, G. I., 2013b, Spiny-Headed Worms (Acanthocephala) of the Birds of Russia: History of Study, Results and Outlook for the Future, Parasitology in Changing World : Proceedings of the $V$ Congress of Russian Society of Parasitologists of the RAS, Ed. by K. V. Galaktionov, All-Russian Conference with International Participations (September 23-26, 2013, ISEA SB RAS, Novosibirsk), Novosibirsk, Garamond, 16.

Atrashkevich, G. I., 2013c, The Biodiversity of SpinyHeaded Worms (Acanthocephala) in Birds from the Asian Subarctic, Conference Dedicaded to the Memory of Academican K. V. Simakov, Conference Proceedings (Magadan, November 26-28, 2013), Ed. by I. A. Chereshnev, Magadan, NESC FEB RAS, 118-120 [In Russian].

Atrashkevich, G. I., 2014, New Data on Fauna, Taxonomy, and Biology of Spiny-Headed Worms (Acanthocephala) from Birds of Russia's Arctic, Transactions of Center for Parasitology, Center for Parasitology of A. N. Severtsov Institute of Ecology and Evolution RAS, Systematics and Ecology of Parasites, Moscow, KMK Scientific Press Ltd., 48, 19-21 [In Russian].

Atrashkevich, G. I., 2017, On the Life of Helminths from Birds in the Arctic (Biodiversity and Life Strategy Exemplified by Acanthocephalans), Conference Dedicated to the Memory of Academician K. V. Simakov, Conference Proceedings (Magadan, November 22-24, 2017), NEISRI FEB RAS, Magadan, 110-112 [In Russian].

Atrashkevich, G. I., 2018, Spine-Headed Worms (Acanthocephala) of the Fauna of Russia: Exploration Degree, Problems and Outlook for the Future, Contemporary Parasitology - Major Trends and Challenges, Proceeding of the VI Congress of the Society of Parasitologists, Russia: International Conference (October 15-19, 2018, Zoological Institute RAS, Saint-Petersburg), Eds. K. V. Galaktionov, S. G. Medvedev, A. Yu. Ryss, A. O. Frolov, St.-Petersburg; Lema Publishing, 22 [In Russian].

Catalogue of Nematode and Acanthocephala Type Specimens in the Helminthological Museum RAS, Editor in Chief S. V. Zinovyeva, Moscow, KMK Scientific Press Ltd., 2009 [In Russian].

Fedorov, V. V.; Chereshnev, I. A.; Nazarkin, M. V.; Shestakov, A. V.; Volobuev, V. V., 2003, Catalog of Marine and Freshwater Fishes of the Northern Part of the Sea of Okhotsk, Vladivostok, Dalnauka [In Russian].

Khokhlova, I. G., 1965, Polymorphus gavii sp. nov. - a New Species of Acanthocephalan from the Loons of Chukotka, Trudy Gelmintol. Lab. Akad. Nauk USSR, Moscow, Nauka, 15, 196-199 [In Russian].

Khokhlova, I. G., 1971, On Revising the genus Polymorphus Lühe, 1911 (Acanthocephala: Polymorphidae), Ibid, Moscow, Nauka, 21, 120-126 [In Russian].

Khokhlova, I. G., 1975, Revision of the Genus Arhythmorhynchus Lühe, 1911 (Acanthocephala: Polymorphidae), Trudy Gelmintol. Lab. Akad. Nauk USSR, Moscow, Nauka, 25, 195-203 [In Russian].

Khokhlova, I. G., 1986, Acanthocephalans of Terrestrial Vertebrates in USSR Fauna, Moscow, Nauka Publishers [In Russian].

Koblik, E. A.; Red'kin, Ya. A.; Arkhipov, V. Yu., 2006, List of Birds of the Russian Federation, Moscow, KMK Scientific Press Ltd. [In Russian]. 
Kretchmar, A. V.; Andreev, A. V.; Kondratyev, A. Ya., 1991, Birds of Northern Plains, Leningrad, Nauka [In Russian].

Lisitsyna, O. I., 2019, Fauna of Ukraine, 31, Acanthocephala, Kiev, Naukova Dumka [In Russian].

Nechaev, V. A.; Gamova, T. V., 2009, Birds of Russia's Far East (Annotated Catalogue), Vladivostok, Dalnauka [In Russian].

Petrochenko,V. I., 1958, Acanthocephala of Domestic and Wild Animals, Moscow, AS SSSR, 2 [In Russian].

Regel, K. V., 2005, Marine and Saline-Water Invertebrates of the Tauysk Bay, Biodiversity of the Tauysk Bay of the Sea of Okhotsk, Vladivostok, Dalnauka, 479-544 [In Russian].
Ryzhikov, K. M.; Rysavy, B.; Khokhlova, I. G.; Tolkatcheva, L. M.; Kornyushin, V. V., 1985, Helminths of Fish-Eating Birds of the Palaearctic Region II. Cestoda and Acanthocephales, Eds. K. M. Ryzhikov, B. Rysavy, Moscow - Prague.

Solovyeva, D. V.; Paruk, J. D., Tash J.; Vartanyan, S. L.; Danilov, G. K.; Pospekhov, V. V.; Evers, D. C., 2017, Population Sizes, Post-Breeding Densities, and Lake Size Partitioning of Loon Species in Western Chukotka, Contemporary Problems of Ecology, 6, 798-811 [In Russian].

Yamaguti, S., 1963, Acanthocephala. Systema Helminthum. Wiley InterScience, New York, London, 5. 